\title{
化学療法中に胆道出血を認めた骨髄癌腫症を伴った $\mathrm{S}$ 状結腸癌の 1 例
}

$\mathrm{JA}$ 北海道厚生連帯広厚生病院外科 ${ }^{1)}$, 北海道大学大学院医学研究院消化器外科学教室 $\mathrm{II}^{2)}$

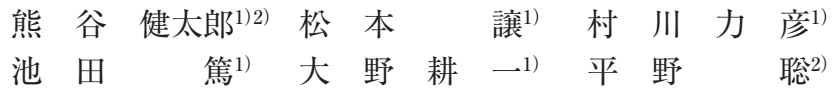

症例は63歳, 男性. DICで発症しS 状結腸癌, 多発骨転移, リンパ節転移, 骨髄癌腫 症の診断で内科に入院し, mFOLFOX6 を行っていた．化学療法開始後22日目に右季肋 部痛と吐血を認め, 急性出血性胆囊炎およびDIC と診断し緊急手術を行った。胆囊は 壊死し, 総胆管内は凝血塊で充満し, 胆道鏡で肝内胆管から下部胆管にかけ灀漫性に胆 管粘膜の発赤と oozing 認め, 胆管炎と診断した，胆摘後に総胆管内にCチューブ『を 留置し手術を終えた，本症例は骨髄癌腫症による凝固異常を背景とし，急性出血性胆囊 炎を発症し, 胆囊内圧上昇による胆囊壊死と凝血塊による閉塞性胆管炎を生じたと考え られた，術後，胆道出血は止血され，化学療法の再開が可能となった，骨髄癌腫症患者 であっても, 急性胆囊炎発症直前の ADLが比較的良好で, 胆囊摘出術後の化学療法再 開で予後延長が期待できれば, 胆囊摘出術も治療の選択肢の一つとなり得ると考えられ た.

索引用語：骨髄癌腫症, 急性出血性胆囊炎, 緩和手術

はじめに

予後不良な患者に全身麻酔下の処置が必要となった 場合, その適応は難しい判断となる。骨髄癌腫症は発 症すると高率に播種性血管内凝固症候群 (Disseminated Intravascular Coagulation；以下 DIC）を発症し予 後不良である ${ }^{1)}$ 。一方, 急性出血性胆囊炎は, 経皮的 胆囊ドレナージの効果は不確かである. 持続的な出血 により胆囊穿孔や閉塞性黄疸, 出血性ショックをきた す可能性があり緊急での胆囊摘出術が必要となる ${ }^{2}$. 今回, S 状結腸癌に起因する骨髄癌腫症患者が化学療 法中にDICを背景とした急性出血性胆囊炎を併発し た. 術前の ADLが良好で胆囊摘出術を施行し化学療 法が再開できれば予後延長が見込めると判断し, 緊急 手術を行ったので報告する.

症例

患者：63歳, 男性.

主訴：右季肋部痛, 吐血.

既往歴：原発性胆汁性胆管炎.

2020年12月18日受付 2021 年 2 月14日採用

〈所属施設住所〉

厂080-0024 带広市西十四条南10丁目 1
現病歴：患者は全身骨痛，DICで発症し，精查目的 の造影 CT でS状結腸に壁肥厚と周囲リンパ節腫脹を 認めた。下部消化管内視鏡検查では $\mathrm{S}$ 状結腸に全周性 の 3 型腫瘍を認め, 生検で低分化腺癌の診断となった. また, DICの精查目的に骨髄穿刺が施行され S 状結腸

Table 1 血液検査所見

\begin{tabular}{llll}
\hline 【血算】 & \multicolumn{3}{c}{ 【生化学】 } \\
\hline $\mathrm{WBC}$ & $11,000 / \mu \mathrm{l}$ & $\mathrm{TP}$ & $5.7 \mathrm{~g} / \mathrm{dl}$ \\
$\mathrm{RBC}$ & $2.23 \times 10^{6} / \mu \mathrm{l}$ & $\mathrm{Alb}$ & $2.5 \mathrm{~g} / \mathrm{dl}$ \\
$\mathrm{Hb}$ & $6.8 \mathrm{~g} / \mathrm{dl}$ & $\mathrm{T}-\mathrm{Bil}$. & $1.8 \mathrm{mg} / \mathrm{dl}$ \\
$\mathrm{Ht}$ & $20.30 \%$ & $\mathrm{CHE}$ & $160 \mathrm{U} / \mathrm{L}$ \\
$\mathrm{Plt}$ & $59,000 / \mu \mathrm{l}$ & $\mathrm{ALP}$ & $3,153 \mathrm{U} / \mathrm{L}$ \\
& & $\mathrm{AST}$ & $188 \mathrm{U} / \mathrm{L}$ \\
& & $\mathrm{ALT}$ & $63 \mathrm{U} / \mathrm{L}$ \\
& & $\mathrm{LD}$ & $198 \mathrm{U} / \mathrm{L}$ \\
& & $\gamma-\mathrm{GTP}$ & $113 \mathrm{U} / \mathrm{L}$ \\
& & $\mathrm{BUN}$ & $7.7 \mathrm{mg} / \mathrm{dl}$ \\
【凝固】 & & $\mathrm{Cre}$ & $0.37 \mathrm{mg} / \mathrm{dl}$ \\
\hline APTT & 31.2 秒 & $\mathrm{Na}$ & $141 \mathrm{mmol} / \mathrm{L}$ \\
$\mathrm{PT} \%$ & $69 \%$ & $\mathrm{~K}$ & $3.5 \mathrm{mmol} / \mathrm{L}$ \\
$\mathrm{PT}$-INR & 1.19 & $\mathrm{Cl}$ & $106 \mathrm{mmol} / \mathrm{L}$ \\
FIB & $287 \mathrm{mg} / \mathrm{dl}$ & $\mathrm{Ca}$ & $7.8 \mathrm{mg} / \mathrm{dl}$ \\
D-dimer & $97.6 \mu \mathrm{g} / \mathrm{ml}$ & $\mathrm{CRP}$ & $3.12 \mathrm{mg} / \mathrm{dl}$ \\
\hline
\end{tabular}




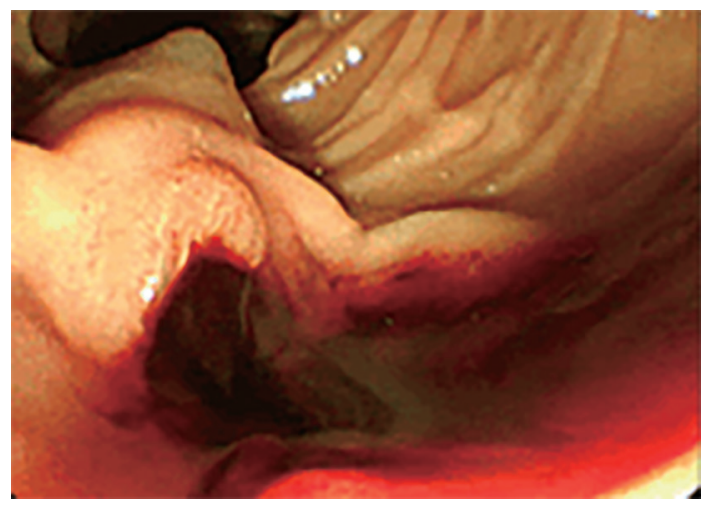

Fig. 1 上部消化管内視鏡検査所見 : Vater 乳頭部から血 液の流出を認めた。

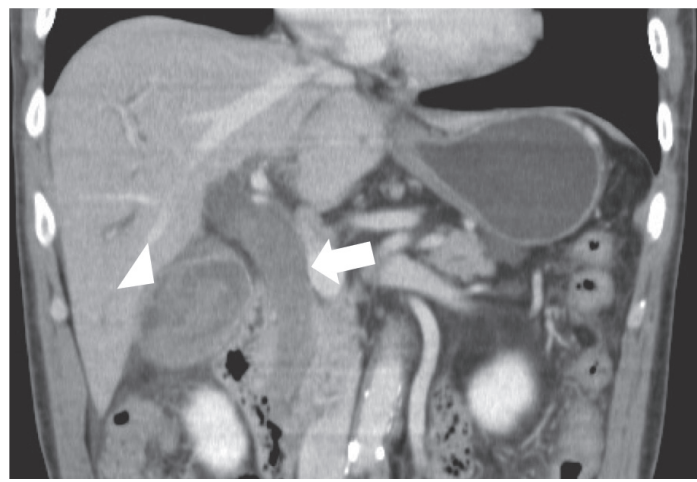

Fig. 2 造影 CT 所見：胆囊の腫大と胆囊内にモザイク状 の高吸収を認めた (矢頭)。また, 総胆管の拡張を認め た (矢印)。胆囊底部の壁が低吸収であった。

癌と同様の低分化腺癌を認め, 以上のことから, S 状 結腸癌（type3, circ, cT3cN1M1), 多発骨転移, リ ンパ節転移, 骨髄癌腫症の診断で消化器内科へ入院し, mFOLFOX6 療法を行っていた，化学療法開始後22日 目（2 コース目投与後 5 日目）に右季肋部痛と吐血を 認めた。

現症: 身長 $162 \mathrm{~cm}$, 体重 $55 \mathrm{~kg}$. 腹部平坦 - やや硬. 心窩部を最強点として圧痛著明. 反跳痛, 筋性防御を 認めた。

血液生化学検査所見 : $\mathrm{Hb} 6.8 \mathrm{~g} / \mathrm{dL}$, Plt 5.9 万 $/ \mu \mathrm{L}$ と 貧血，血小板減少を認めた。WBC $11,000 / \mu \mathrm{L} ， \mathrm{CRP}$ $3.12 \mathrm{mg} / \mathrm{dL}$ と炎症反応の上昇を認めた．直接ビリルビ ン優位のビリルビン上昇, 肝胆道系酵素の上昇を認め た.PT-INR・APTTはともに延長は認めなかったが D ダイマーは著明高值であり，急性期 DIC の基準を満

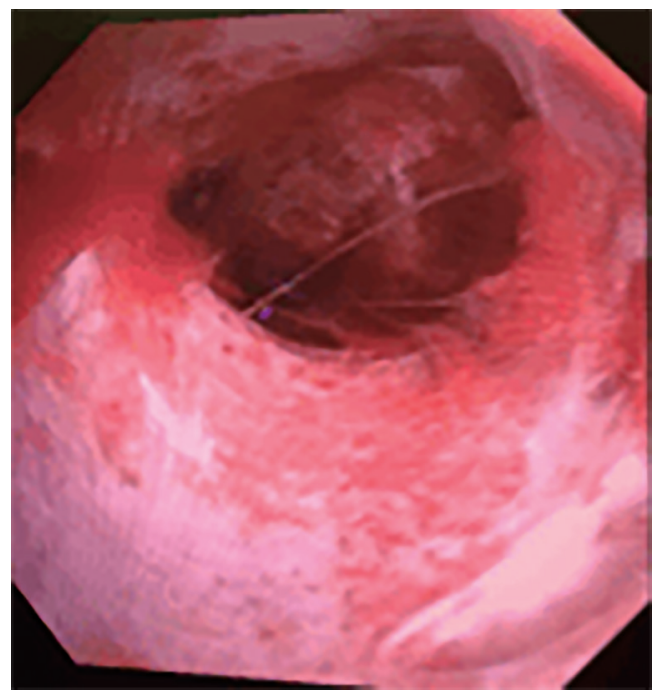

Fig. 3 術中胆道鏡所見 : 胆管粘膜は霂漫性に発赤を 認め, oozingを伴っていた。

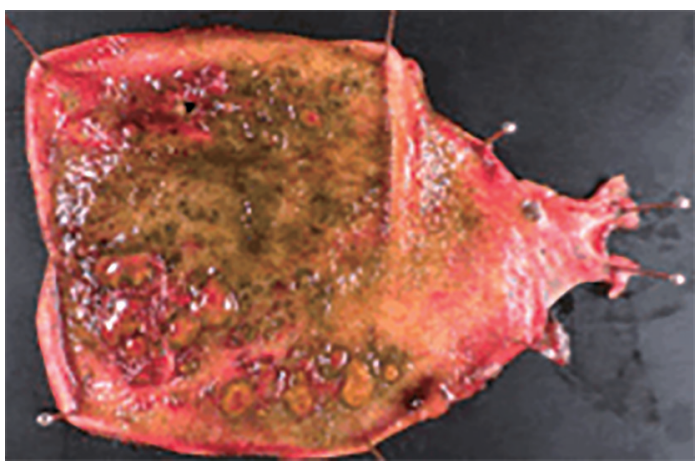

Fig. 4 胆囊摘出標本：広範な粘膜壊死認めたが, 血管 の破綻は明らかではなかった。

たしていた（Table 1).

上部消化管内視鏡検査所見：食道，胃には明らかな 出血源を認めなかった。 十二指腸 Vater 乳頭部に暗赤 色の凝血塊を認めた，鉗子で凝血塊を摘除すると，乳 頭部から血液の流出が見られた（Fig. 1).

腹部造影 CT 所見：胆囊腫大を認め, 内部はモザイ ク状の高吸収域を認め, 胆囊出血が疑われた。また, 胆管拡張も認め, 内部は胆汁より高吸収であることか ら胆管内への血液の流出が考えられた．胆囊周囲に低 吸収域認め, 底部の胆囊壁に造影不領域を認めたこと から壞疽性胆囊炎が疑われた（Fig. 2)。

以上より，急性出血性胆囊炎（Tokyo Guidelines 
2018（以下 TG18）; Grade II, ASA-PS ; 3E, Charlson comorbidity index (CCI)； 6 点 $)^{3)}$, および凝血 塊による閉塞性胆管炎と診断した。中枢神経や心肺肝 腎など主要臓器障害なく, 発症直前のPSO と ADLも 良好なため耐術可能と判断し, また, 骨骨癌腫症は胆 摘後に化学療法を再開できれば 3 カ月以上の予後が見 込めると判断し, 緊急手術を行うこととした.

手術所見 : 腹垫鏡下胆囊摘出術を試みたが胆囊は壊 死し, 胆囊の緊満が強く胆囊の把持が困難であり開腹 手術へと移行した. 総胆管を切開したところ胆管内に 充満する凝血塊を認め, これを摘出した。 また, 胆管 内を洗浄するも出血が持続し, 術中胆道鏡にて胆管粘 膜の発赤と oozing を認め, 胆管炎と診断した (Fig. 3). 完全な止血は困難であると判断し, 胆囊摘出後に総胆管 内にCチューブ®を留置し手術を終了した。手術時間は 2 時間 45 分, 出血量 $420 \mathrm{ml}$, 赤血球濃厚液 (red cell concentrate：RBC） 4 単位の輸血を要した.

病理組織学的所見：広範な粘膜壊死, 出血, 好中球 浸潤で示される急性胆囊炎の像を認めたが，血管の破 綻は明らかではなかった。また，悪性所見を認めなか った（Fig. 4).

術後経過 : 術後も貧血の進行があり, RBC 8 単位, 新鮮凍結血漿 (fresh frozen plasma：FFP) 6 単位の 輸血を要したが腹部症状は劇的に改善し, 術後 8 日目 にCチューブ®を抜去し, 術後14日目に消化器内科へ 転科した。術後20日目に化学療法（mFOLFOX6）が 再開されたが，間もなく患者の希望で化学療法中止と なり, 緩和治療のみとなった。術後65日目に原病死し た.

\section{考察}

胆道出血は，胆管あるいは膵管から出血をきたし血 液が十二指腸乳頭部に到達した状態と定義され，その 原因として医原性，胆石，胆管炎，動脈瘤，腫瘍性な どが挙げられる4)。本症例では, 腹痛と吐血がみられ, 上部消化管内視鏡のVater 乳頭部からの出血の所見 と, 造影 CTでのモザイク状の高吸収を伴う胆囊腫大 の所見から急性出血性胆囊炎と診断し, 緊急手術を行 った．手術所見からは骨髄癌腫症による凝固異常を背 景とし, 急性出血性胆囊炎を発症し, 胆囊内圧上昇に よる胆囊壊死と凝血塊による閉塞性胆管炎を発症した と考えられた。

予後不良な患者に急性胆囊炎を併発した場合, 抗菌 薬治療やPTGBD などの手術以外の治療法が選択され ることが一般的と思われる。TG18ではGrade I，
Grade II の急性胆囊炎ではCCI 6 点以上，または ASA-PS 3 以上を高リスクとし, 抗菌薬・ドレナージ などの治療後に待機的手術を検討することを推奨して いる, 一方, 出血性胆囊炎の治療も, 非出血性胆囊炎 と同様に保存加療, 保存加療後の待機的手術, 緊急手 術が挙げられるが, 保存加療による治療効果は不確定 である. 保存加療後に待機的手術が可能であった症例 の報告5) 見られるが, 持続的な出血が認められる場 合には胆囊穿孔や閉塞性黄疸, 出血性ショックをきた す可能性がある ${ }^{2)}$. 凝血塊によりドレナージ不良とな り緊急手術を要した症例 (6) や, 抗凝固療法中に発症し た症例でドレナージを先行させようとしたが持続する 出血により手技に難渋し緊急手術を要した症例も存在 する7).こうした背景からも出血性胆囊炎と診断がつ き次第, 緊急胆囊摘出術を行った報告が多い8). 本症 例は胆囊内に血液㧍よび凝血塊が充満しており, PTGBDでのドレナージが無効であった場合, 胆囊穿 孔による沉発性腹膜炎の危険があり, 既にDICも併 発していることからもドレナージのみの治療では予後 不良の可能性があると考えられた，急性胆囊炎として の重症度はGrade II でASA-PS 3E, CCI 6 点と手術 の高リスク群であったが, 救命のためには胆囊摘出術 が最適と考え, また, 急性胆囊炎発症直前のPSO と ADLが良好であったことから耐術可能と判断し手術 を行った。

骨髄癌腫症は, 腫瘍細胞が骨髄内に多発性かつ広範 囲に転移し，骨髄組織が腫瘍細胞に置換された状態と 定義される，血行性転移が生じやすく，一般的に未分 化なものほど骨䯣への転移が多く, 組織型は腺癌が多 いとされる. 貧血・腰背部痛・出血症状を 3 主徵とし, 発症すると高率にDICを合併し予後不良であるとさ れる. 確定診断は骨髄穿刺によりなされる ${ }^{9)}$. 本症例 では全身骨痛，DIC 抒よび骨髄穿刺にて低分化腺癌の 骨髄転移像を認め, DICを伴った骨髄癌腫症と診断し た。癌腫別では胃癌が最も多く大腸癌での報告は比較 的稀である ${ }^{10)}$. 医学中央雑誌で「大腸癌」「骨髄癌」「骨 髄転移」のキーワードで1980年 8 月から 2020 年 8 月まで で検索したところ, 会議録を除いて 34 例の症例報告を 認めた (Table 2) ${ }^{11) ~ 44)}$. 本症例を含めた 35 例で, 男女比 は23対12 と男性が多い傾向にあった. 発症年齢は21歳 から78歳で中央值は61歳であり, 60歳以上の発症が半 数以上を占めるが 20 代での発症を 4 例で認めた。 組織 型では低分化腺癌が16例と最多で, 次いで印環細胞癌 が 8 例であり, 悪性度の高い組織型で骨髄癌腫症の発 
Table 2 本邦における大腸癌骨髄癌腫症の報告例

\begin{tabular}{|c|c|c|c|c|c|c|c|c|}
\hline 症例 & 著者 & 報告年 & 年齢 & 性別 & 部位 & 病理 & 化学療法 & 転㷌 \\
\hline 1 & 柳川 & 1984 & 60 & $\mathrm{~F}$ & A & muc & $(-)$ & 22日 (死亡) \\
\hline 2 & 原武 & 1985 & 56 & $\mathrm{~F}$ & $\mathrm{C}$ & carcinoid & $(-)$ & 390日 (死亡) \\
\hline 3 & 小野寺 & 1990 & 27 & & $\mathrm{C}$ & por & $(-)$ & 40日 (死亡) \\
\hline 4 & 渡辺 & 1990 & 78 & $\mathrm{~F}$ & S & por & $(-)$ & 60 日 (死亡) \\
\hline 5 & 長谷川 & 1991 & 66 & M & $\mathrm{T}$ & muc & $(-)$ & 20日 (死亡) \\
\hline 6 & Yoshioka & 1992 & 62 & M & $\mathrm{R}$ & tub2 & $(-)$ & 13日 (死亡) \\
\hline 7 & 佐藤 & 1999 & 63 & M & $\mathrm{R}$ & sig & 5-FU & 90日 (死亡) \\
\hline 8 & 倉田 & 2000 & 53 & M & S & por & MTX/5-FU & 68日 (死亡) \\
\hline 9 & 稲木 & 2000 & 59 & M & $\mathrm{A}$ & sig & $\mathrm{CBDCA} / 5-\mathrm{FU}$ & 90日 (死亡) \\
\hline 10 & 菊池 & 2002 & 26 & M & S & por & $\begin{array}{l}\mathrm{CPT}-11 / \mathrm{CDDP} \\
\mathrm{MTX} / 5 \mathrm{FU}\end{array}$ & 84日 (死亡) \\
\hline 11 & 内田 & 2002 & 63 & M & $\mathrm{R}$ & sig & 不明 & 22 日 (死亡) \\
\hline 12 & 中澤 & 2002 & 57 & $\mathrm{~F}$ & A & tub1 & $(-)$ & 53日 (死亡) \\
\hline 13 & 広瀬 & 2002 & 37 & M & $\mathrm{R}$ & muc & $5-\mathrm{FU}$ & 90日 (死亡) \\
\hline 14 & 廣川 & 2003 & 70 & $\mathrm{~F}$ & $\mathrm{R} / \mathrm{C}$ & por & $(-)$ & 30日 (死亡) \\
\hline 15 & 永島 & 2005 & 74 & $\mathrm{~F}$ & A & tubl & $(-)$ & 50日 (死亡) \\
\hline 16 & 牧野 & 2005 & 55 & $\mathrm{~F}$ & S & sig & $(-)$ & 21日 (死亡) \\
\hline 17 & 田島 & 2006 & 48 & M & $\mathrm{A}$ & por & $(-)$ & 56日 (死亡) \\
\hline 18 & 大西 & 2007 & 21 & $\mathrm{~F}$ & $\mathrm{R}$ & sig & MTX/5-FU & 90日 (死亡) \\
\hline 19 & 中㟝 & 2007 & 26 & $\mathrm{~F}$ & $\mathrm{~T}$ & por & UFT/LV/CPT-11 & 180日 (死亡) \\
\hline 20 & 小菅 & 2007 & 59 & $\mathrm{~F}$ & $\mathrm{~T}$ & por & $\mathrm{MTX} / 5-\mathrm{FU}$ & 180日 (生存) \\
\hline 21 & 小林 & 2009 & 70 & M & $\mathrm{R}$ & por & mFOLFIRI & 210日 (生存) \\
\hline 22 & 清水 & 2009 & 65 & M & A & tub2 & $(-)$ & 90日 (死亡) \\
\hline 23 & 野中 & 2010 & 45 & $\mathrm{~F}$ & $\mathrm{R}$ & por & mFOLFOX6/bevacizumab & 210日 (生存) \\
\hline 24 & 濱口 & 2011 & 76 & M & $\mathrm{R}$ & tub2 & $(-)$ & 26日 (死亡) \\
\hline 25 & 上藤 & 2011 & 32 & M & S & por & $\begin{array}{l}\text { mFOLFOX } 6 \\
\text { FOLFIRI }\end{array}$ & 240日 (死亡) \\
\hline 26 & 東山 & 2011 & 71 & M & $\mathrm{R}$ & por & mFOLFOX6 & 150日 (生存) \\
\hline 27 & 磯崎 & 2011 & 45 & M & $\mathrm{D}$ & por & mFOLFOX6 & 230日 (死亡) \\
\hline 28 & 山崎 & 2013 & 68 & M & $\mathrm{S}$ & muc & FOLFOX4/bevacizumab & 210日 (生存) \\
\hline 29 & 鈴木 & 2014 & 58 & M & $\mathrm{C}$ & por & SOX/bevacizumab & 292日 (死亡) \\
\hline 30 & 天野 & 2015 & 66 & $\mathrm{~F}$ & $\mathrm{C}$ & tub2 & mFOLFOX6 & 292日 (死亡) \\
\hline 31 & 長久 & 2015 & 70 & M & $\mathrm{S}$ & sig & CPT-11/panitumumab & 135日 (死亡) \\
\hline 32 & 吉田 & 2016 & 61 & M & $\mathrm{T}$ & sig & $\begin{array}{l}\text { XELOX/bevacizumab } \\
\text { mFOLFOX6/panitumumab }\end{array}$ & 210日 (死亡) \\
\hline 33 & 森 & 2018 & 66 & M & $\mathrm{R}$ & por & $\begin{array}{l}\text { FOLFIRI/panitumumab } \\
\text { XELOX/bevacizumab } \\
\text { regorafenib }\end{array}$ & 600日 (死亡) \\
\hline 34 & 宮訔 & 2019 & 72 & & A & sig & $(-)$ & 14日 (死亡) \\
\hline 35 & 本症例 & 2021 & 63 & M & S & por & mFOLFOX6 & 122日 (死亡) \\
\hline
\end{tabular}

症が多い傾向にあると思われる。平均生存期間は 133.7 日であるが, 化学療法を施行した20例では188.7日であ り，化学療法により生存期間の改善が期待される。ま た，2010年以降では分子標的薬を併用した症例が報告 され，分子標的治療を併用し四次治療まで治療を行い 20力月の生存を得た症例もみられた。このことから骨 髄癌腫症患者に打いて，分子標的薬を併用した全身化 学療法が施行可能であれば数力月から年単位の予後が
得られる可能性が示唆される，癌腫別で最も頻度が高 い胃癌骨髄癌腫症について, 菊池ら ${ }^{45}$ は100症例の検討 を行っているが，全生存期間中央值は 3 カ月であり化 学療法施行群では 4 力月と報告しており，胃癌におい ても化学療法施行群で有意に生存期間の延長を認めて いる。，一方，進行・末期癌患者に対する症状緩和手術 の有用性については，前田ら ${ }^{46)}$ の報告がある，手術適 応について彼らは，予想余命 2 力月以上を原則とする 
が，それ以下と思われる症例でも oncologic emergency症例や, 手術により患者の QOLが改善される場合, としていた。 その結果, $12.7 \%$ に手術直接死亡を, 術 後合併症を $49.5 \%$ に認め，また，緊急手術例では待機 手術例に比べ手術直接死亡率が有意に高かった（31\% vs 9.3\%）と報告している。この研究において, 症状緩 和手術は一定の効果が得られQOL改善に貢献するが, 十分なインフォームドコンセントが重要と結論づけて いる. S 状結腸癌に骨髄癌腫症を伴うという病態は進 行・末期癌の状態と言えるが, 本症例はその上に急性 出血性胆囊炎を併発するという病態であった，急性胆 囊炎の発症が化学療法開始22日目と治療開始間もない 時期であり，胆摘後に化学療法を再開できれば 3 カ月 以上の予後が見込めると判断し手術を行った．その結 果, 術後20日目に化学療法を再開でき, 症状緩和手術 として一定の効果を得ることができたと考えている.

\section{結語}

高度進行癌治療中に凝固異常を背景とした急性出血 性胆囊炎を発症した 1 例を経験した。現病の予後が不 良であっても, 胆囊炎発症直前の ADLが比較的良好 で, 胆囊摘出術後の化学療法再開で予後延長が期待で きれば，緊急的胆囊摘出術も治療の選択肢の一つとな り得ると考えられた。

利益相反：なし

\section{文献}

1）天野浩司, 中田 健, 辻江正樹他：盲腸癌による 播種性骨髄癌腫症に合併したDICに対して mFOLFOX6療法が著効した 1 例. 癌と化療 $2015 ; 42: 2106-2108$

2）伊藤博道, 淀縄 聡：肝十二指腸間膜内血腫によ り閉塞性横断を合併した出血性胆囊穿孔の 1 例. 胆道 $2014 ; 28: 667-672$

3）急性胆管炎・胆曧炎診療ガイドライン改訂出版委 員会/編 急性胆管炎・胆震炎診療ガイドライン 2018. 第 3 版, 医学図書出版, 東京, 2018, p112 $-113$

4) Sandblom P : Hemobilia. Surg Clin North Am $1973 ; 53: 1191-1201$

5）東 敏弥, 山田卓也, 辻本浩人他：保存的治療後 に腹胿鏡下胆囊摘出術を施行した出血性胆囊炎の 1 例. 日外科系連会誌 $2017 ; 42: 244-251$

6）林俊治, 舩越 徹, 喜納政哉他: 胆囊体部に発 生したDieulafoy 潰瘍が原因となった出血性胆囊
炎の 1 例。日臨外会誌 $2014 ; 75: 2280-2283$

7) 松清 大, 渡邊 学, 浅井浩司他: 抗凝固療法中 の脳梗塞患者に発症した急性出血性胆囊炎の 1 例. 胆道 $2014 ; 28: 808-814$

8）片野 薰, 山口貴久, 宮下知治他：直接経口抗凝 固薬内服中に胆囊穿孔, 腹腔内出血に至った出血 性胆震炎の 1 例。 日腹部救急医会誌 $2019 ; 39$ ： $141-144$

9）吉川直之：骨髄癌腫症．検と技 $2015 ； 43 ： 1032$ $-1034$

10）林 秀夫，春山春江，江村芳丈他：播種性骨䯣癌 症一転移癌の一病型としての考察ならびに microangiopathic hemolytic anemiaまたはdisseminated intravascular coagulation との関連について 一. 癌の臨 $1979 ; 25: 329-343$

11）柳川昌弘，柴垣文夫，河野富雄他：DICを増悪さ せた広範骨転移を伴った上行結腸膠様癌の 1 手術 例．兵庫全外科医会誌 $1984 ; 80$ 号 : 55-58

12）原武譲二, 堀江昭夫：骨髄癌腫症の臨床病理学的 検討。癌の臨 $1985 ; 31: 168-178$

13）小野寺秀, 川村詔導, 三宅高義他：播種性骨䯣癌 症を呈した若年性大腸癌の 1 例。現代医療 $1990 ; 22: 451-457$

14）渡辺 敏，竜 崇正，柳沢真司他：骨髄転移を来 した消化器癌症例について. 腹部救急診療の進歩 $1990 ; 10: 488-491$

15）長谷川日出子, 小林京子, 岩橋和敏他：大腸癌（粘 液癌）による播種性骨䯣癌症の 1 例一本邦におけ る播種性骨髄癌症報告例の統計的観察一，歯科学 報 $1991 ； 91: 193-198$

16) Yoshioka K, Shimizu H, Yokoo S, et al : Disseminated carcinomatosis of bone marrow from submucosal carcinoma in adenoma of the rectum Intern Med $1992 ; 31: 1056-1059$

17）佐藤尚也, 玉内登志雄, 小林一郎他：細小血管障 害性溶血性貧血（Microangiopathic HemolyticAnemia）を合併した消化器癌による骨髄癌症の 2 例. 袋井市民病研誌 $1999 ； 8 ： 98-104$

18）倉田昌直, 高田泰次, 川本 徹他：S状結腸癌術 後骨髄癌症によるDICに対し, MTX-5FU交代 療法が有効であった 1 例。日臨外会誌 2000 ； $61: 1256-1260$

19）稲木紀幸, 吉羽秀麿, 芝原一繁他：骨䯣癌症をき たした上行結腸印環細胞癌の 1 例. 消外 2000 ； $23: 1729-1734$ 
20）菊池由宣，萩原良美，高橋敬二他：骨髄癌症を合 併した若年者びまん浸潤型大癌の 1 例. Gastroenterol Endosc 2002； $44: 1949-1954$

21）内田治仁, 日野理彦, 岡本志朗他：骨髄癌症を来 し播種性血管内凝固を合併した直腸癌の 1 例。共 済医報 $2002 ； 51 ： 236-240$

22）中澤 哲，梁 英樹，吉田一成他：播種性骨髄癌 症を来した上行結腸癌の 1 例. 日消外会誌 $2002 ; 35: 431-435$

23）広瀬由紀，松下利雄，山本広幸他：播種性骨髄癌 症をきたした若年者大腸粘液癌の 1 例. 日臨外会 誌 $2002 ; 63: 964-966$

24）廣川文鋭，尾野光市，林堂元紀他：播種性骨髄癌 症をきたした直腸・横行結腸癌の 1 例。日臨外会 誌 $2003 ; 64: 2238-2243$

25）永島由紀子, 井手衆哉, 重松正森：腰痛を主訴と した播種性骨髄癌症と考えられた 1 例。整外と災 外 $2005 ; 54: 77-80$

26）牧野知紀，三嶋秀行，池永雅一他：術後早期に播 種性骨髄癌症をきたしたS状結腸印環細胞癌の 1 例. 日臨外会誌 $2005 ; 66: 124-128$

27）田島隆行, 向井正哉, 檜 友也他：播種性骨髄癌 症により術後急激な経過をたどった上行結腸低分 化型腺癌の 1 例. 日消外会誌 $2006 ; 39 ： 265-$ 270

28）大西顕司，上田順彦，千田勝紀他：播種性骨髄癌 症にて再発した若年者大腸印環細胞癌の 1 例。日 臨外会誌 $2007 ; 68: 136-141$

29）中㟝隆行, 野中良和, 進藤久和他：播種性骨髄癌 症をきたした若年性大腸癌の 1 例。日臨外会誌 $2007 ; 68: 394-397$

30）小菅 誠, 小川匡市, 渡部通章他：播種性骨髄癌 症による播種性血管内凝固症候群に対して MTX/5-FU 療法が奏効した横行結腸低分化型腺 癌の 1 例. 日臨外会誌 $2007 ; 68: 943-947$

31）小林建司, 安部真梨子, 上田修久他：modified FOLFIRIで病理組織学的CRを得た後に急激に骨 髄転移から DICを来たした直腸低分化型腺癌の 1 例. 日本大腸肛門病会誌 $2009 ; 62: 65-71$

32）清水孝王, 千田 匡 : 播種性骨髄癌症により急激 な経過をたどった上行結腸癌の 1 例。新潟医会誌 $2009 ; 123: 135-141$

33）野中健太郎, 車 清吾, 伊東通裕他：mFOLFOX-6/Bevacizumabが奏効した播種性骨髄癌症 で発症した直腸低分化型腺癌の 1 例。日消誌
$2010 ； 107: 1151-1158$

34）濱口雄平, 有光竜樹, 馬場園豊他：直腸癌術後早 期に急激な播種性骨髄癌症をきたした 1 例. 日臨 外会誌 $2011 ; 72: 444-447$

35）上藤和彦，松本佑介，牟田 直：播種性血管内凝 固症候群を伴った骨髄癌症に対してmFOLFOX6 療法が奏効した 4 型大腸癌の 1 例。日消外会誌 $2011 ; 44: 318-324$

36）東山明日美, 工藤峰生, 長佐古友和他：好酸球増 多で発症し化学療法が著効した直腸癌による骨䯣 癌腫症の 1 例. 日消誌 $2011 ; 108: 1244-1251$

37）磯崎 豊, 山西正芳, 宇都宮栄他：mFOLFOX6 療法にてDICの改善をみた大腸癌による骨髄癌 腫症の 1 例. 癌と化療 $2011 ; 38: 1705-1708$

38）山崎健路, 勝村直樹, 小澤範高：FOLFOX4/ Bevacizumabが奏効した $\mathrm{S}$ 状結腸粘液癌による播 種性骨髄癌腫症の 1 例。癌と化療 $2013 ； 40$ ： $1105-1109$

39）鈴木大聡，松岡信子，牛丸裕貴他：SOX/Bevacizumab療法で改善した大腸癌骨髄癌腫症による DICの 1 例. 癌と化療 $2014 ; 41: 1013-1016$

40）天野浩司，中田 健，辻江正樹他：盲腸癌による 播種性骨髄癌腫症に合併したDICに対して mFOLFOX6療法が著効した 1 例。癌と化療 $2015 ; 42: 2106-2108$

41）長久吉雄, 陳開, 服部晋明他 : CPT- $11 / \mathrm{Pa}$ nitumumabが奏効した大腸印環細胞癌による播 種性骨髄癌腫症の 1 例。癌と化療 $2015 ; 42$ ： $2477-2479$

42）吉田陽一郎，山下裕一，長谷川桀：結腸癌による 播種性骨髄癌症の診断と治療のポイントとは? 内科 $2016 ; 17: 986-991$

43）森総一郎, 酒田和也, 太田博文他：化学療法が奏 効し 1 年 8 力月生存した直腸癌播種性骨髄癌症の 1 例. 日臨外会誌 $2018 ; 79: 118-123$

44）宮崇安晃, 山邊和生, 林 伸泰他：急激な転帰を たどった上行結腸癌による播種性骨髄癌症の 1 例. 癌と化療 $2019 ; 46: 285-287$

45）菊池由宣，松崎淳人，戸倉夏木他：胃癌骨髄癌腫 症 本邦報告例および自験例の検討．東邦医会誌 $2010 ; 57: 127-136$

46）前田好章, 篠原敏樹, 濱口 純他：消化器外科に おける進行・末期癌患者に対する症状緩和手術 165例の検討. 日臨外会誌 $2013 ; 74: 1138-$ 1144 


\title{
A CASE OF EMERGENCY SURGERY FOR BILIARY HEMORRHAGE DURING CHEMOTHERAPY FOR SIGMOID COLON CANCER ACCOMPANIED BY MYELOCARCINOMATOSIS
}

\author{
Kentaro KUMAGAI ${ }^{12)}$, Joe MATSUMOTO ${ }^{1}$, Katsuhiko MURAKAWA ${ }^{1)}$, \\ Atsushi $\mathrm{IKEDA}^{1)}$, Koichi $\mathrm{ONO}^{1)}$ and Satoshi HIRANO ${ }^{2)}$ \\ Department of Surgery, JA Hokkaido Koseiren Obihiro Kosei General Hospital ${ }^{1)}$ \\ Department of Gastroenterological Surgery II, Hokkaido University Faculty of Medicine ${ }^{2)}$
}

A 63-year-old man, who was diagnosed with DIC, sigmoid colon cancer, multiple bone and lymph node metastases, and myelocarcinomatosis, was admitted to our hospital. He received chemotherapy with mFOLFOX6;22 days later, right hypochondriac pain and hematemesis were observed. Due to acute hemorrhagic cholecystitis and DIC, emergency surgery was performed. Gallbladder necrosis and blood clots in the common bile duct were observed. Intraoperative cholangioscopy revealed diffuse mucosal redness and fluid oozing from the intrahepatic duct to the lower bile duct. Cholecystectomy was performed, and a biliary decompression tube was placed in the common bile duct via the remaining cystic duct ( $\mathrm{C}$ tube). It was considered that acute hemorrhagic cholecystitis occurred due to coagulopathy caused by myelocarcinoma. Moreover, increased pressure in the gallbladder led to necrosis, clotting, and obstructive cholangitis. After surgery, biliary bleeding stopped completely, and chemotherapy was restarted. Even in patients with myelocarcinomatosis, cholecystectomy may be a treatment option in patients with relatively good ADL before the onset of acute cholecystitis and in cases where prognosis can be prolonged and chemotherapy can be restarted after cholecystectomy.

Key words : myelocarcinoma, acute hemorrhagic cholecystitis, palliative surgery 